\section{OPEN ACCESS}

Edited by:

Khawar Jabran,

Nigde Ömer Halisdemir

University, Turkey

Reviewed by:

Md Asaduzzaman,

New South Wales Department of

Primary Industries, Australia

Simerjeet Kaur

Punjab Agricultural University, India

*Correspondence:

llias Travlos

travlos@aua.gr

Specialty section:

This article was submitted to

Weed Management,

a section of the journal

Frontiers in Agronomy

Received: 20 December 2019

Accepted: 28 February 2020

Published: 31 March 2020

Citation:

Travlos I, Gazoulis I, Kanatas P,

Tsekoura A, Zannopoulos S and Papastylianou P (2020) Key Factors Affecting Weed Seeds' Germination, Weed Emergence, and Their Possible Role for the Efficacy of False Seedbed

Technique as Weed Management

Practice. Front. Agron. 2:1

doi: 10.3389/fagro.2020.00001

\title{
Key Factors Affecting Weed Seeds' Germination, Weed Emergence, and Their Possible Role for the Efficacy of False Seedbed Technique as Weed Management Practice
}

\section{Ilias Travlos ${ }^{1 *}$, Ioannis Gazoulis ${ }^{1}$, Panagiotis Kanatas ${ }^{2}$, Anastasia Tsekoura ${ }^{1}$, Stavros Zannopoulos ${ }^{3}$ and Panayiota Papastylianou ${ }^{1}$}

${ }^{1}$ Laboratory of Agronomy, Department of Crop Science, Agricultural University of Athens, Athens, Greece, ${ }^{2}$ Agricultural Cooperative of Mesolonghi-Nafpaktia, Missolonghi, Greece, ${ }^{3}$ Koniareio Citrus Institute, Ministry of Rural Development \& Food, Kechries, Greece

Important parameters that influence weed seeds' germination and seedlings' emergence can also affect the efficacy of false seedbed as weed management practice. These parameters consist of environmental factors such as soil temperature, soil water potential, exposure to light, fluctuating temperatures, nitrates concentration, soil $\mathrm{pH}$, and the gaseous environment of the soil. Soil temperature and soil water potential can exert a great influence on composition of the weed flora of a cultivated area. Base soil temperatures and base water potential for germination vary among different weed species and their values can possibly be used to predict which weeds will emerge in a field as well as the timing of emergence. Predicting the main flush of weeds in the field could maximize the efficacy of false seedbed technique as weed management practice. Timing, depth, and type of tillage are important factors affecting weed emergence and, subsequently, the efficacy of false seedbed. The importance of shallow tillage as a weed control method in the false seedbed technique has been highlighted. Further research is needed to understand and explain all the factors that can affect weed emergence so as to maximize the effectiveness of eco-friendly weed management practices such as false seedbed in different soils and under various climatic conditions.

Keywords: false seedbed, soil temperature, dormancy, seed germination, weed emergence, tillage

\section{INTRODUCTION}

Weeds that exist with crops early in the season are less detrimental than weeds that compete with the crop later in the growing season, and this principle has supported the timely use of weed management practices (Wyse, 1992). Either early- or late-emerging weeds produce great proportions of viable seeds that can remain in the soil profiles for a long time period, contributing to the perpetuation and the success of weeds (Cavers and Benoit, 1989). As a result, in most arable crop systems, weed management strategies focus mainly on reducing weed density in the early stages of crop growth (Zimdahl, 1988). However, confining weed management to a narrow temporal window increases the risk of unsatisfactory weed management due to unfavorable weather 
(Gunsolus and Buhler, 1999). Weed seed banks are the primary source of persistent weed infestations in agricultural fields (Cousens and Mortimer, 1995) and if their deposits are increased, greater herbicide doses are required to control weeds afterwards (Taylor and Hartzler R, 2000). Annual weed species increase their populations via seed production exclusively (Steinmann and Klingebiel, 2004), whereas seed production is also important for the spread of perennials (Blumenthal and Jordan, 2001).

Consequently, it is preferable to focus on depleting the seed stock in the soil through time rather than viewing weeds just as an annual threat to agricultural production (Jones and Medd, 2000). This approach is reinforced not only by ecological (Davis et al., 2003) but also by economic simulation models (Jones and Medd, 2000). False seedbed technique is a method providing weed seed bank depletion. The principle of flushing out germinable weed seeds before crop sowing forms the basis of the false seedbed technique in which soil cultivation may take place days or weeks before cropping (Johnson and Mullinix, 1995). Germination of weed seeds is stimulated through soil cultivation (Caldwell and Mohler, 2001). Irrigation is suggested to provide the adequate soil moisture required for sufficient weed emergence. In the case of false seedbed, emerged weeds are controlled by shallow tillage operations (Merfield, 2013). Control of weeds and crop establishment should be delayed until the main flush of emergence has passed in order to deplete the seedbank in the surface layer of soil and reduce subsequent weed emergence (Bond and Grundy, 2001).

False seedbed technique aims to reduce weed seed bank by exploiting seed germination biology. Thus, the efficacy of such management practices is directly associated with all the factors affecting germination of weed seeds and seedling emergence. Soil temperature, diurnal temperature variation, soil moisture, light, nitrates concentration in the soil, and the gaseous environment of the soil can regulate seed germination and weed emergence (Merfield, 2013). Except for the case of environmental factors, tillage is the most effective way to promote weed seed germination because the soil disturbance associated with tillage offers several cues to seedbank residents such as elevated and greater diurnal temperature, exposure to light, oxygen, and release of nitrates in the soil environment (Mohler, 2001). The aim of this review paper is to give prominence to the significance of environmental factors and tillage for weed seed germination and seedlings emergence and, therefore, for the efficacy of false seedbed technique as weed management practice.

\section{THE IMPACT OF SOIL TEMPERATURE AND WATER POTENTIAL ON WEED SEED GERMINATION AND THEIR ROLES FOR PREDICTING WEED EMERGENCE}

The longevity of weed seeds into the soil profiles is attributed to the phenomenon of dormancy that prevents seed germination even when the environmental conditions are ideal (BenechArnold et al., 2000). Dormancy is distinguished into two types: primary and secondary dormancy (Karssen, 1982). The end of primary dormancy is sequenced by the establishment of secondary dormancy and this sequence has been defined as dormancy cycling (Baskin and Baskin, 1998). In adapted weed species, dormancy is alleviated during the season preceding the period with favorable conditions for seedling development and plant growth, while dormancy induction takes place in the period preceding the season with environmental conditions unsuitable for plant survival (Benech-Arnold et al., 2000). Furthermore, seeds from summer annual species are released from dormancy by low winter temperatures. High summer temperatures may induce entrance of the same seeds into dormancy again, which is referred to as secondary dormancy. On the contrary, seeds from winter annuals are released from dormancy by high summer temperatures whereas low winter temperatures induce their entrance into secondary dormancy (Forcella et al., 2000). Relatively dry seeds lose dormancy at a rate which is temperaturedependent. In hydrated seeds, high temperatures reinforce or induce dormancy whereas low temperatures between -1 and $15^{\circ} \mathrm{C}$ may stimulate germination (Roberts, 1988).

Timing of weed emergence is dependent on the timing and rate of seed germination, which is dependent not only on soil temperature and but also on moisture potential (Gardarin et al., 2010). Of the many environmental factors that regulate seed behavior under field conditions, soil temperature has a primary influence on seed dormancy and germination, affecting both the capacity for germination by regulating dormancy and the rate or speed of germination in non-dormant seeds (Bouwmeester and Karssen, 1992). It has been recognized since at least 1860 that three cardinal temperatures (minimum, optimum, and maximum) describe the range of $T$ over which seeds of a particular species can germinate (Bewley and Black, 1994). The minimum or base temperature $\left(T_{\mathrm{b}}\right)$ is the lowest $T$ at which germination can occur, the optimum temperature $\left(T_{\mathrm{o}}\right)$ is the $T$ at which germination is most rapid, and the maximum or ceiling temperature $\left(T_{\mathrm{c}}\right)$ is the highest $T$ at which seeds can germinate. Seed germination rates also vary with increasing temperature as it increases in the suboptimal range and decreases above the optimum temperature (Alvarado and Bradford, 2002).

To account for the effect of temperature on the progress of germination, the concept of thermal time has been developed (Garcia-Huidobro et al., 1982). The application of thermal time theory to germination is based on the observation that for some species there is a temperature range over which the germination rate for a particular fraction of the seed population is linearly related to temperature. The base temperature $T_{\mathrm{b}}$ is estimated as the $\mathrm{x}$-intercept of a linear regression of the germination rate with temperature (Gummerson, 1986). Once seeds have lost dormancy, their rate of germination shows a positive linear relationship between the base temperature and the optimum temperature and a negative linear relationship between the optimal temperature and the ceiling temperature (Roberts, 1988). For the case of the summer annual Polygonum aviculare (L.), Kruk and Benech-Arnold (1998) demonstrated that low winter temperatures alleviate dormancy, producing a widening of the thermal range permissive for germination as a consequence of a progressive decrease of the lower limit temperature for germination of the population $\left(T_{\mathrm{b}}\right)$. In contrast, high summer temperatures reinforce dormancy, which results in a narrowing 
of the thermal range permissive for germination through an increase of $T_{\mathrm{b}}$.

Germination speed of Alopecurus myosuroides (Huds.) seeds decreased with temperature, whereas the final proportion of germinated seeds was not significantly influenced (Colbach et al., 2002b). Minimum temperature required for seed germination is different for various weed species. Minimum temperature required for seed germination has been estimated at $0^{\circ} \mathrm{C}$ both for the winter annual A. myosuroides (Colbach et al., 2002a) and the summer annual P. aviculare (Batlla and Benech-Arnold, 2005). However, Masin et al. (2005) estimated the base temperature for Digitaria sanguinalis (L.), Setaria viridis (L.), P. Beauv., Setaria pumila (Poir.), Roem. \& Schultes and Eleusine indica (L.), at $8.4,6.1,8.3$, and $12.6^{\circ} \mathrm{C}$, respectively. Moreover, the mean $T_{\mathrm{b}}$ recorded for summer annuals Amaranthus albus (L), Amaranthus palmeri (S. Wats.), D. sanguinalis, Echinochloa crusgalli (L.) Beauv., Portulaca oleracea (L.), and Setaria glauca (L.) was $\sim 40 \%$ higher as compared to the corresponding value recorded for winter annuals Hirschfeldia incana (L.) and Sonchus oleraceus (L.). Optimal temperature conditions required for terminating dormancy status vary among different species. For example, Panicum miliaceum (L.) seeds lost dormancy at $8^{\circ} \mathrm{C}$ while $P$. aviculare seeds were released from dormancy at $17^{\circ} \mathrm{C}$ (Batlla and Benech-Arnold, 2005). The two germination response characteristics, $T_{\mathrm{b}}$ and rate, influence a species' germination behavior in the field (Steinmaus et al., 2000). Extended models should be developed to predict the effects of environment and agricultural practices on weed germination, weed emergence, and the dynamics of weed communities in the long term. This requires estimating the baseline temperature for germination for each weed species that are dominant in a cultivated area and recording seed germination in a wide range of temperatures (Gardarin et al., 2010).

The knowledge about seed germination for the dominant weed species of a cultivated area is vital for predicting weed seedlings emergence. The possibility of predicting seedling emergence is essential for improving weed management decisions. However, weed emergence is the result of two distinct processes, i.e., germination and pre-emergence growth of shoots and roots, which react differently to environmental factors and should therefore be studied and modeled separately (Colbach et al., 2002a). In temperate regions, soil temperature is probably the most distinct and recognizable factor governing emergence (Forcella et al., 2000). Soil temperature can be used as a predictor of seedling emergence in crop growth models (Angus et al., 1981). Soil temperature can also be used for predicting weed emergence, but only if emergence can be represented by a simple continuous cumulative sigmoidal curve and the upper few centimeters of soil remain continuously moist (Forcella et al., 2000).

Fluctuating temperatures belong to parameters that can remove the constraints for the seed germination of many weed species once the degree of dormancy is sufficiently low (Benech-Arnold et al., 2000). In particular, the extent and number of diurnal soil temperature fluctuations can be critical in lessening seed dormancy of several species. For example, alternating temperatures at $25{ }^{\circ} \mathrm{C}$ increased germination of Amaranthus retroflexus (L.), Amaranthus spinosus (L.), and
Amaranthus tuberculatus (L.) from 23 to 65,8 to 77 , and 9 to $57 \%$, respectively, as compared to non-alternating temperatures. Fluctuating temperatures from 2.4 to $15^{\circ} \mathrm{C}$ can terminate the dormancy situation in Chenopodium album (L.) seeds (Murdoch et al., 1989). Either four diurnal cycles of $12^{\circ} \mathrm{C}$ amplitude or 12 diurnal cycles of $6^{\circ} \mathrm{C}$ amplitude were necessary for the emergence of D. sanguinalis (King and Oliver, 1994). The number of cycles of alternating temperatures needed to end the dormancy situation has to be investigated. In Sorghum halepense (L.) Pers., a 50\% increase in cycles of alternating temperatures can double the number of seeds that are released from dormancy (Benech-Arnold et al., 1990). Furthermore, if the demand for fluctuating temperatures to terminate dormancy in the seeds of this species is not satisfied, a loss of sensitivity to fluctuating temperatures occurs in a proportion of the population (Benech-Arnold et al., 1988). The variation among weed species regarding the demands for fluctuating temperatures for seed germination points out the need for further investigation regarding the effects of fluctuating temperatures in germination of noxious weed species in different regions around the world and under various soil and climatic conditions.

Soil moisture is a key parameter affecting the seed dormancy status of many species (Benech-Arnold et al., 2000; Batlla et al., 2004). First of all, the environmental conditions existing during seed development in parent plants and seed maturation affect the relative dormancy of the seeds. Less dormant seeds of Sinapis arvensis (L.) were produced from the mother plants under water stress conditions (Wright et al., 1999) while similar results have been reported regarding either winter annual grass species Avena fatua (L.) or summer perennial S. halepense (Peters, 1982; Benech-Arnold et al., 1992). Moreover, sufficient water potential has been noticed to increase the production of dormant $A$. myosuroides seeds (Swain et al., 2006).

The effects of water deficits on seed germination have been encapsulated in the "hydrotime" concept. This idea was first illustrated by Gummerson (1986) and further explained by (Bradford, 1995). The model of (Bradford, 1995) accounted for dormancy loss during after-ripening through changes in the base water potential of the seeds' environment that permits $50 \%$ germination $\left(\Psi_{\mathrm{b}(50)}\right)$. Christensen et al. (1996) confirmed that $\Psi_{\mathrm{b}(50)}$ value of the population is decreased by the change in $\Psi_{\mathrm{b}(50)}$ due to after-ripening. The $\Psi_{\mathrm{b}(50)}$ value is saved as the $\Psi_{\mathrm{b}(50)}$ value of the population and serves as the initial value for the next time step. The process continues until the $\Psi_{\mathrm{b}(50)}$ value of fully after-ripened seeds is reached. The model described is only to consider dormancy changes, not only in relation to the thermal environment, but also as a function of the soil water status. The loss of primary dormancy does not secure some species germination if moisture demands are not met. For example, adequate water conditions are demanded to promote germination of Bromus tectorum (L.) (Bauer et al., 1998). Bauer et al. (1998) assumed that the temperaturedependent after-ripening process in this winter annual occurs at soil water potentials below $\sim-4 \mathrm{MPa}$. Martinez-Ghersa et al. (1997) reported that increased water content promoted seed germination of A. retroflexus, C. album, and E. cruss-galli. 
The seed germination response to the soil water potential of wild plants could be correlated with the soil water status in their natural habitats (Evans and Etherington, 1990). The models which aim to predict weed germination and emergence need to record seed germination in a wide range of water potentials. Seeds of various weed species require different values of water potential in order to germinate. For instance, the base water potential $\Psi_{\mathrm{b}}$ for $A$. myosuroides was estimated at $-1.53(\mathrm{MPa})$ in the study of Colbach et al. (2002b) whereas the corresponding value recorded for Ambrosia artemisiifolia (L.) was $-0.8(\mathrm{MPa})$ as observed by other scientists (Shrestha et al., 1999). The value of minimum water potential for the germination of $S$. viridis seeds was $-0.7(\mathrm{MPa})$ (Masin et al., 2005) whereas the corresponding value recorded for Stellaria media (L.) Villars was -1.13 ( $\mathrm{MPa})$ (Grundy et al., 2000). Dorsainvil et al. (2005) revealed that the base water potential for germination for Sinapis alba (L.) was at -1 (MPa). Regarding weed emergence, although seeds of many species can germinate in a wide range of water potentials, once germination has occurred the emerged seedlings are sensitive to dehydration, and irreversible cellular damage may occur (Evans and Etherington, 1991). False seedbed is a technique that aims to deplete weed seed banks by eliminating the emerged weed seedlings. Thus, it is crucial to have knowledge about water demands for germination for the dominant weed species of the agricultural area where a false seedbed is planned to be formed. If these demands are not met, then they can be secured via adequate irrigation in the meantime between seedbed preparation and crop sowing.

\section{THE POSSIBLE EFFECTS OF LIGHT, GASEOUS ENVIRONMENT OF THE SOIL, SOIL NITRATES CONTENT AND SOIL PH ON SEED GERMINATION OF VARIOUS WEED SPECIES}

The reaction of seeds to light signals is dependent on phytochromes that consist of a group of proteins acting as sensors to changes in light conditions. Cancellation of dormancy by light is mediated by the phytochromes. All phytochromes have two mutually photoconvertible forms: Pfr (considered the active form) with maximum absorption at $730 \mathrm{~nm}$ and $\operatorname{Pr}$ with maximum absorption at $660 \mathrm{~nm}$. The photoconversion of phytochrome in the red light (R)-absorbing form (Pr) to the far red light (FR)-absorbing form (Pfr), has been identified as part of the germination induction mechanism in many plant species (Gallagher and Cardina, 1998). Germination can be induced by $\mathrm{Pfr} / \mathrm{P}$ as low as $10^{-4}$ and is usually saturated by $<0.03 \mathrm{Pfr} / \mathrm{Pr}$ (Benech-Arnold et al., 2000). The quality of light received by seeds may be more important than the quantity. There is evidence that Far-red light (FR, about $735 \mathrm{~nm}$ ) can inhibit germination (Ballaré et al., 1992). Regarding the way weed emergence is influenced by light, given that FR or the ratio of FR to red light ( $\mathrm{R}$, about $645 \mathrm{~nm}$ ) increases as plant canopies develop and solar elevation decreases with time after the summer period, emergence of sensitive species should be inhibited during the summer period. However, the practical significance of FR exposure for emergence in field settings is not well-known (Forcella et al., 2000).

Solanum sarrachoides (Sendtn.) seeds germination rate was recorded over $90 \%$ in both light and dark conditions (Zhou et al., 2005). However, seeds of several species require light for germination. Lower than $16 \%$ germination percentages were recorded for Anchusa arvensis (L.) M. Bieb., A. Fatua, and Lamium amplexicaule (L.) in light while germination of Matricaria perforata (Mérat), Galinsoga ciliata (Raf. Blake), and Sonchus asper (L.) Hill reached the level of $99 \%$ due to exposure to light (Milberg et al., 2000). Germination of Bidens tripartita (L.), Carex flacca (Schreb.), Juncus conglomeratus (L.), and Scirpus sylvaticus (L.) was also found to be enhanced by light (Grime et al., 1981) whereas with no exposure to light, seeds of Chenopodium bonus-henricus (L.) Rchb were not able to germinate (Khan and Karssen, 1980). However, the results of (Gallagher and Cardina, 1998) indicated that light was a requirement for germination in $<20 \%$ of seeds within populations of Amaranthus spp. and also that the same seeds were the most dormant out of the total amount of seeds in the soil seedbank. Light and a higher temperature of $25^{\circ} \mathrm{C}$ promoted faster, uniform germination of seeds of (Taraxacum officinale (L.), while in darkness, the achievement of $50 \%$ of the final germination percentage was delayed and a longer mean emergence time was needed (Letchamo and Gosselin, 1996). Other scientists noticed that germination of E. crussgalli was increased by $65 \%$ under light conditions as compared to darkness [Boyd and Van Acker, 2004]. In contrast to the findings of the studies presented above, exposure to light has been found to have inhibiting effects on seed germination of Galium spurium (L.) (Malik and Vanden Born, 1987). In Bromus sterilis (L.) (Hilton, 1982) and some lines of A. fatua (Hou and Simpson, 1993), germination is inhibited by a single $\mathrm{R}$ pulse and this inhibition is abolished by a subsequent FR pulse. Therefore, light appears in some cases to function as a dormancy breaking signal when deeply buried seeds are moved to shallower soil depths, whereas in other cases exposure of seeds to light may inhibit germination in various ways depending on the species and circumstances. For the purposes of emergence modeling, the role of light requirements for seed germination needs to be investigated as they set a large and unexplored research area.

There is evidence showing that other environmental factors, such as nitrates and gases, can also regulate seed bank dormancy (Bewley and Black, 1982; Benech-Arnold et al., 2000). For instance, germination of Sysimbrium offcinale (L.) Scop. is dependent on the simultaneous presence of light and nitrates (Hilhorst and Karssen, 1988), while in the case of Arabidopsis thaliana (L.) Heynh., nitrates modify light-induced germination to some degree (Derkx and Karssen, 1994). The seeds of summer annual species, S.officinale, showed increased sensitivity to nitrates and lost dormancy during the winter season (Hilhorst, 1990). Regarding the winter annual S. arvensis, Goudey et al. (1988) recorded maximal germination frequencies when $\mathrm{NO}_{3}^{-}$ content ranged from 0.3 to $4.4 \mathrm{nmol} \mathrm{seed}{ }^{-1}$ for applied $\mathrm{NO}_{3}^{-}$ 
concentrations between 2.5 and $20 \mathrm{~mol} \mathrm{~m}^{-3}$. In the same study germination was significantly lower in seeds containing more than $5 \mathrm{nmol} \mathrm{NO}_{3}^{-}$. Although the mechanisms by which nitrates stimulate dormancy loss remain under investigation, they maybe act somewhere at the cell membrane environment (Karssen and Hilhorst, 1992). The evaluation of the effects of nitrates in regulating weed seeds' germination and weed emergence is an area of interest for weed scientists and research needs to be carried out to get a better knowledge regarding this issue. There is also evidence that the range of $\mathrm{pH}$ values can promote germination of important weed species. For instance, Pierce et al. (1999) noticed that seed germination of D. sanguinalis decreased with increasing $\mathrm{pH}$ when soil was amended with $\mathrm{MgCO}_{3}$, whereas maximum root dry weights occurred at ranges from $\mathrm{pH}$ 5.3-5.8. A pH range of 5-10 did not influence seed germination of E. indica (Chauhan and Johnson, 2008). Cyperus esculentus (L.) germination rate at $\mathrm{pH} 3$ was $14 \%$ as compared to $47 \%$ at $\mathrm{pH} 7$, while germination of Sida spinosa (L.) was highest at $\mathrm{pH} 9$ (Singh and Singh, 2009). In the experiment by (Lu et al., 2006) Eupatorium adenophorum (Spreng.) germinated in a narrow range of $\mathrm{pH}(5-7)$ whereas other researchers recorded a 19-36\% germination rate for Conyza canadensis (L.) Cronquist. over a $\mathrm{pH}$ range from 4 to 10 (Nandula et al., 2006). As a consequence, another area available for research is the role of soil $\mathrm{pH}$ on seed germination and weed emergence especially in fields where false seedbed technique has been planned to be applied.

Oxygen and carbon dioxide are two of the most major biologically active gases in soil. Oxygen concentration in soil air does not usually fall below the limit of 19\% (BenechArnold et al., 2000). During storage of seeds in soil, oxygen can have both detrimental and beneficial effects on the dormancy status of weed seeds. Results of an early study carried out by Symons et al. (1986) revealed that introduction to the cycle of secondary dormancy in the seeds of A. fatua was attributed to hypoxia. Hypoxic conditions did also cause a decrease in the germination capacity and rate of Datura stramonium (L.) (Benvenuti and Macchia, 1995). Moreover, B. tripartita seeds showed increased germination rates under 5 and $10 \%$ oxygen concentration as compared to the germination rate recorded under 21\% oxygen concentration (Benvenuti and Macchia, 1997). Germination of E. crus-galli was increased with oxygen concentrations in the range among 2.5 and $5 \%$ and declined when the oxygen concentration level was above 5\% citepbib20. However, low oxygen concentration or the inability to remove anaerobic fermentation products from the gaseous environment directly surrounding the seed may inhibit seed germination. The results of Corbineau and Côme (1988) indicated that low oxygen concentrations, or even hypoxia, can terminate dormancy situation in the seeds of Oldenlandia corymbosa (L.). The results of Experiment 1 carried out by Boyd and Van Acker (2004) revealed that oxygen concentration of $21 \%$ highest led to 31,29 , and $61 \%$ increased germination of Elymus repens (L.) Gould. as compared to oxygen concentrations of 5, 10, and $2.5 \%$. In the same experiment, the greatest germination rate for Thlaspi arvense (L.) was also recorded with $21 \%$ oxygen concentration.
The levels of carbon dioxide in soil air ranges between 0.5 and $1 \%$ (Karssen, 1980a,b). When soils are flooded, the ratio of carbon dioxide to oxygen typically increases and can have detrimental effects on seed germination and seedling emergence. In very early studies, concentrations of carbon dioxide in the range of 0.5 and $1 \%$ have been reported to have a dormancy breaking effect in seeds of Trifolium subterraneum (L.) and Trigonella ornithopoides (L.) Lam. \& DC. (Ballard, 1958, 1967). Elevated carbon dioxide concentrations combined with low oxygen concentrations may further strengthen the signal to germinate and promote germination below the surface during periods of high soil moisture content (Yoshioka et al., 1998), and this hypothesis was supported by the results of (Boyd and Van Acker, 2004). Ethylene, a gas with a wellknown role as a growth regulator, is also present in the soil environment, with its usual value of the pressure ranging between 0.05 and 1.2 MPa (Corbineau and Côme, 1995). At these concentrations, it has break-dormancy effects on seeds of T. subterraneum (Esashi and Leopold, 1969), P. oleracea, C. album, and $A$. retroflexus (Taylorson, 1979). According to Katoh and Esashi (1975), at low concentrations in the soil ethylene promotes germination in Xanthium pennsylvanicum (L.) and similar observations have been made regarding A.retroflexus (Schönbeck and Egley, 1981a,b). However, these are results of old studies and it should be noted that a newer study stated that the role of ethylene in governing seed germination and seedling emergence cannot be clearly explained (Baskin and Baskin, 1998). The findings of another study where strains of a bacterium were evaluated as stimulators of emergence for parasite weeds belonging to Striga spp. were interesting. The bacterium Pseudomonas syringae (Van Hall) pathovar glycinea synthesizes relatively large amounts of ethylene. In the study of Berner et al. (1999) strains of P. syringae pv. glycinea had a stimulatory effect on the germination of seeds of the parasite weeds Striga aspera (Willd.) Benth. and Striga gesnerioides (Willd.) Vatke. Consequently, whether oxygen, carbon dioxide, and ethylene influences weed seeds' germination and seedlings emergence is not yet clarified since variation has been reported among gases' concentrations and various weed species. Thus, the role of the gaseous environment of the soil in seed germination and weed emergence needs to be further explained.

\section{THE IMPORTANCE OF TILLAGE AS STIMULATOR OF WEED EMERGENCE AND AS WEED CONTROL METHOD IN FALSE SEEDBED TECHNIQUE}

The movement of the weed seeds within the soil profiles as a consequence of tillage creates variations in the dormancy of seeds (Ghersa et al., 1992). There is evidence that weed species' timing and duration of emergence varies (Stoller and Wax, 1973; Egley and Williams, 1991), suggesting that timing of tillage interferes with the timing of species germination and acts as an assembly filter of weed communities (Smith, 2006). The results of Crawley (2004) revealed that the frequency of 
Papaver dubium (L.), A. thaliana, and Viola arvensis (Murray) was increased by $62.5,66.5$, and $72 \%$, respectively, due to fall cultivation. In the same study, spring cultivation increased the frequency of C. album, Bromus hordeaceus (L.), and Galinsoga parviflora (Cav.) by 48, 88, and $92.5 \%$. Spring tillage acts as a filter on initial community assembly by hindering the establishment of later-emerging forbs, winter annuals, C3 grasses, and species with biennial and perennial life cycles, whereas fall tillage prevents the establishment of early-emerging spring annual forbs and C4 grasses. Species adapted to emerge earlier are therefore able to exploit the high availability of soil resources and be more competitive as compared to species that usually emerge later in the growing season when soil resource availability is restricted at a significant point (Davis et al., 2000).

Tillage events confined to the top $10 \mathrm{~cm}$ can provoke greater weed emergence than the corresponding events usually observed in untilled soil (Egley, 1989). Although no direct evidence exists of the effect of tillage on dormancy through modification of temperature fluctuations or nitrate concentration, it is wellknown that tillage exposes seeds to a light flash before reburial, allows for greater diffusion of oxygen into and carbon dioxide out of the soil, buries residue, and promotes drying of the soil, thereby increasing the amplitude of temperature fluctuations and promoting nitrogen mineralization (Mohler, 1993). Tillage promotes seed germination, and this is a fundamental principle in which innovative management practices such as stale seedbed techniques that target the weed seed bank are based (Riemens et al., 2007). Weed emergence is an inevitable result of shallow soil disturbances in crop production, as it is indicated by Longchamps et al. (2012). Disturbances as small as wheel tracking can enhance seedling emergence. Results from past studies point out that promotion of seedling emergence is more dependent on the density of a given recruitment cohort rather than flush frequency (Myers et al., 2005; Schutte et al., 2013), and that the stimulatory effect of a particular shallow soil disturbance event dissipates over time and flushes occurring afterward feature seedling densities are similar to flushes recorded in untilled soils (Mulugeta and Stoltenberg, 1997; Chauhan et al., 2006). Plants react to the low fidelity between germination cues and recruitment potential and have become able to produce seed populations with different germination demands not only in qualitative but also in quantitative points to secure the longevity of the population. Thus, only a fraction of a population can germinate after performing shallow tillage operations (Childs et al., 2010). Soil type can also affect seedbank dynamics as it was shown by the results of a study conducted in Ohio. When the soil was sampled at $15 \mathrm{~cm}$ depth, the concentration of seeds was reduced with depth but the effect of tillage on seed depth was not the same for all three soil types that received the same tillage operation (Cardina et al., 1991).

False seedbed technique is based on the principle of using soil disturbance to provoke weed emergence and use shallow tillage instead of herbicide as a weed control method before crop establishment. False seedbed by inter cultivation decreased weed density and dry weight in finger millet (Patil et al., 2013).
It is well-established that $5 \mathrm{~cm}$ is the maximum depth of emergence for most cropping weeds. If tillage overpasses this boundary, non-dormant seeds from deeper soil profiles are placed in germinable superficial soil positions. Re-tillage must be as shallow as $2 \mathrm{~cm}$. Spring tine can be used in false seedbeds and multiple passes are suggested for more efficient weed control in cereal crops, while milling bed formers are more suited to vegetable crops (Merfield, 2013). Johnson and Mullinix (1995) found that shallow tillage was efficient against weeds like $C$. esculentus, Desmodium tortuosum (L.), and Panicum texanum (L.) in peanuts in a false seedbed. Similar results have also been observed in soybeans (Jain and Tiwari, 1995). An issue remaining under investigation is if the timing of weed elimination can affect the efficacy of such techniques. The results of Sindhu et al. (2010) were not clear regarding which treatment was superior among the stale seedbed prepared for seven days and the one prepared for 14 days before controlling weeds with tillage operations.

\section{CONCLUSIONS}

Important parameters that influence weed seeds' germination and seedlings' emergence can affect the efficacy of false seedbed as weed management practice. These parameters consist of environmental factors such as soil temperature, soil water potential, exposure to light, fluctuating temperatures, nitrates concentration, soil $\mathrm{pH}$, and the gaseous environment of the soil. Soil temperature and soil water potential can exert a great influence on weed diversity of a cultivated area. Estimating minimum soil temperatures and values of water potential for germination for the dominant weed species of a cultivated area can give researchers the ability to predict weed infestation in a field and also the timing of weed emergence. Predicting weed emergence can answer the question of how much time weed control and crop sowing should be delayed in a specific agricultural area where false seedbed technique is about to be applied. As a result, if it was possible in the future to use environmental factors to make such predictions, this could maximize the efficacy of false seedbed technique as weed management practice. Timing, depth, and type of tillage are important factors affecting weed emergence and, subsequently, the efficacy of false seedbed. The importance of shallow tillage as a weed control method in the false seedbed technique has also been highlighted. In general, estimating the effects of environmental factors and tillage operations on weed emergence can lead to the development of successful weed management practices. Further research is needed to understand the parameters that influence weed emergence in order to optimize eco-friendly management practices such as false seedbeds in different soil and climatic conditions.

\section{AUTHOR CONTRIBUTIONS}

All authors listed have made a substantial, direct and intellectual contribution to the work, and approved it for publication. 


\section{REFERENCES}

Alvarado, V., and Bradford, K. J. (2002). A hydrothermal time model explains the cardinal temperatures for seed germination. Plant Cell Environ. 25, 1061-1069. doi: 10.1046/j.1365-3040.2002.00894.x

Angus, J. F., Cunningham, R. B., Moncur, M. W., and Mackenzie, D. H. (1981). Phasic development in field crops. I. thermal response in the seedling phase. Field Crops Res. 3, 365-378. doi: 10.1016/0378-4290(80)90042-8

Ballard, L. A. T. (1958). Studies of dormancy in the seeds of subterranean clover (Trifolium subterraneum L.). I. breaking of dormancy by carbon dioxide and by activated carbon. Aust. J. Biol. Sci. 11, 246-260. doi: 10.1071/BI9580246

Ballard, L. A. T. (1967). "Effects of carbon dioxide on the germination of leguminous seeds," in Physiology, Ecology, and Biochemistry of Germination, 1st Edn. ed H. Borriss (Greifswald: Ernst-Moritz-Arndt Universität), 209-219.

Ballaré, C. L., Scopel, A. L., Sanchez, R. A., and Radosevich, S. R. (1992). Photomorphogenic processes in the agricultural environment. Photochem. Photobiol. 56, 777-788. doi: 10.1111/j.1751-1097.1992.tb02234.x

Baskin, C. C., and Baskin, J. M. (1998). Seeds: Ecology, Biogeography, and, Evolution of Dormancy and Germination. New York, NY: Academic Press. doi: 10.1017/CBO9780511525445.004

Batlla, D., and Benech-Arnold, R. L. (2005). Changes in the light sensitivity of buried Polygonum aviculare seeds in relation to cold-induced dormancy loss: development of a predictive model. New Phytol. 165, 445-452. doi: 10.1111/j.1469-8137.2004.01262.x

Batlla, D., Kruk, B. C., and Benech-Arnold, R. L. (2004). "Modelling changes in dormancy in weed soil seed banks: implications for the prediction of weed emergence," in Handbook of Seed Physiology: Applications to Agriculture, eds R. L. Benech-Arnold and R. A. Sánchez (New York, NY: Haworth Press), 245-264.

Bauer, M. C., Meyer, S., and Allen, P. S. (1998). A simulation model to predict seed dormancy loss in the field for Bromus tectorum L. J. Exp. Bot. 49, 1235-1244. doi: $10.1093 /$ jexbot $/ 49.324 .1235$

Benech-Arnold, R. L., Fenner, M., and Edwards, P. J. (1992). Changes in dormancy level in Sorghum halepense seeds induced by water stress during seed development. Funct. Ecol. 6, 596-605. doi: 10.2307/2390058

Benech-Arnold, R. L., Ghersa, C. M., Sánchez, R. A., and Garcia-Fernandez, A. E. (1988). The role of fluctuating temperatures in the germination and establishment of Sorghum halepense (L.) Pers. Regulation of germination under leaf canopies. Funct. Ecol. 2, 311-318. doi: 10.2307/2389403

Benech-Arnold, R. L., Ghersa, C. M., Sánchez, R. A., and Insausti, P. (1990). A mathematical model to predict Sorghum halepense (L.) Pers. seedling emergence in relation to soil temperature. Weed Res. 30, 91-99. doi: 10.1111/j.1365-3180.1990.tb01691.x

Benech-Arnold, R. L., Sánchez, R. A., Forcella, F., Kruk, B. C., and Ghersa, C. M. (2000). Environmental control of dormancy in weed seed soil banks. Field Crops Res. 67, 105-122. doi: 10.1016/S0378-4290(00)00087-3

Benvenuti, S., and Macchia, M. (1995). Effect of hypoxia on buried weed seed germination. Weed Res. 35, 343-351. doi: 10.1111/j.1365-3180.1995.tb01629.x

Benvenuti, S., and Macchia, M. (1997). Germination ecophysiology of bur beggarticks (Bidens tripartita) as affected by light and oxygen. Weed Sci. $45,696-700$.

Berner, D. K., Schaad, N. W., and Völksch, B. (1999). Use of ethylene-producing bacteria for stimulation of Striga spp. seed germination. Biol. Control 15, 274-282. doi: 10.1006/bcon.1999.0718

Bewley, J. D., and Black, M. (1994). Seeds: Physiology of Development and Germination, 2nd Edn. New York, NY: Plenum Press. doi: $10.1007 / 978-1-4899-1002-8$

Bewley, J. D., and Black, M. (eds.). (1982). "Viability and longevity," in Physiology and Biochemistry of Seeds in Relation to Germination, (Berlin: Springer), 1-59. doi: 10.1007/978-3-642-68643-6_1

Blumenthal, D., and Jordan, N. (2001). Weeds in field margins: a spatially explicit simulation analysis of Canada thistle population dynamics. Weed Sci. 49, 509-519. doi: 10.1614/0043-1745(2001)049[0509:WIFMAS]2.0.CO;2

Bond, W., and Grundy, A. C. (2001). Non-chemical weed management in organic farming systems. Weed Res. 41, 383-405. doi: 10.1046/j.1365-3180.2001.00246.x

Bouwmeester, H. J., and Karssen, C. M. (1992). The dual role of temperature in the regulation of the seasonal changes in dormancy and germination of seeds of Polygonum persicaria L. Oecologia 90, 88-94. doi: 10.1007/BF00317813
Boyd, N., and Van Acker, R. (2004). Seed germination of common weed species as affected by oxygen concentration, light, and osmotic potential. Weed Sci. 52, 589-596. doi: 10.1614/WS-03-15R2

Bradford, K. J. (1995). "Water relations in seed germination," in Seed Development and Germination, eds J. Kigel, and G. Galili (New York, NY: Marcel Dekker, Inc.), 351-396.

Caldwell, B., and Mohler, C. L. (2001). Stale seedbed practices for vegetable production. Hortscience 36, 703-705. doi: 10.21273/HORTSCI.36.4.703

Cardina, J., Regnier, E., and Harrison, K. (1991). Long-term tillage effects on seed banks in three ohio soils. Weed Sci. 39, 186-194. doi: $10.1017 /$ S0043174500071459

Cavers, P. B., and Benoit, D. L. (1989). "Seedbanks in arable land," in Ecology of Soil Seed Banks, eds M. A. Leck, V. T. Parker, and R. L. Simpson (San Diego, CA: Academic Press), 309-328. doi: 10.1016/B978-0-12-440405-2.50019-1

Chauhan, B. S., Gill, G., and Preston, C. (2006). Seedling recruitment pattern and depth of recruitment of 10 weed species in minimum tillage and no-till seeding systems. Weed Sci. 54, 658-668. doi: 10.1614/WS-05-135R.1

Chauhan, B. S., and Johnson, D. E. (2008). Germination ecology of goosegrass (Eleusine indica): an important grass weed of rainfed rice. Weed Sci. 56, 699-706. doi: 10.1614/WS-08-048.1

Childs, D. Z., Metcalf, C. J. E., and Rees, M. (2010). Evolutionary bet-hedging in the real world: empirical evidence and challenges revealed by plants. Proc. Biol. Sci. 277, 3055-3064. doi: 10.1098/rspb.2010.0707

Christensen, M., Meyer, S. E., and Allen, P. S. (1996). A hydrothermal time model of seed after-ripening in Bromus tectorum L. Seed Sci. Res. 6, 155-164. doi: 10.1017/s0960258500003214

Colbach, N., Chauvel, B., Durr, C., and Richard, G. (2002a). Effect of environmental conditions on Alopecurus myosuroides germination. I. effect of temperature and light. Weed Res. 42, 210-221. doi: 10.1046/j.1365-3180.2002.00279.x

Colbach, N., Dürr, C., Chauvel, B., and Richard, G. (2002b). Effect of environmental conditions on Alopecurus myosuroides germination. II. effect of moisture conditions and storage length. Weed Res. 42, 222-230. doi: 10.1046/j.0043-1737.2002.00280.x

Corbineau, F., and Côme, D. (1988). Primary and secondary dormancies in Oldenlandia corymbosa L. seed. Life Sci. Adv. Plant Physiol. 7, 35-39.

Corbineau, F., and Côme, D. (1995). "Control of seed germination and dormancy by the gaseous environment," in Seed Development and Germination, eds J. Kigel, and A. Galili (New York, NY: Marcel Dekker), 397-424. doi: 10.1201/9780203740071-14

Cousens, R., and Mortimer, M. (1995). Dynamics of Weed Populations. Cambridge: Cambridge University Press. doi: 10.1017/CBO9780511608629

Crawley, M. J. (2004). Timing of disturbance and coexistence in a speciesrich ruderal plant community. Ecology 85, 3277-3288. doi: 10.1890/03-0804

Davis, A. S., Dixon, P. M., and Liebman, M. (2003). Cropping system effects on giant foxtail (Setaria faberi) demography: II. retrospective perturbation analysis. Weed Sci. 51, 930-939. doi: 10.1614/P2002-133C

Davis, M. A., Grime, J. P., and Thompson, K. (2000). Fluctuating resources in plant communities: a general theory of invisibility. J. Ecol. 88, 528-534. doi: $10.1046 / j .1365-2745.2000 .00473 . x$

Derkx, M. P. M., and Karssen, C. M. (1994). Are seasonal dormancy patterns in Arabidopsis thaliana regulated by changes in seed sensitivity to light, nitrate and gibberellin? Ann. Bot. 73, 129-136. doi: 10.1006/anbo.1994.1015

Dorsainvil, F., Dürr, C., Justes, E., and Carrera, A. (2005). Characterisation and modelling of white mustard (Sinapis alba L.) emergence under several sowing conditions. Eur. J. Agron. 23, 146-158. doi: 10.1016/j.eja.2004.11.002

Egley, G. H. (1989). Stimulation of weed seed germination in soil. Rev Weed Sci. $2,67-89$.

Egley, G. H., and Williams, R. D. (1991). Emergence periodicity of six summer annual weed species. Weed Sci. 39, 595-600. doi: 10.1017/S0043174500088433

Esashi, Y., and Leopold, A. C. (1969). Dormancy regulation in subterranean clover seeds by ethylene. Plant Physiol. 44, 1470-1472. doi: 10.1104/pp.44.10.1470

Evans, C. E., and Etherington, J. R. (1990). The effect of soil water potential on seed germination of some British plants. New Phytol. 115, 539-548. doi: $10.1111 / j .1469-8137.1990 . t b 00482 . x$

Evans, C. E., and Etherington, J. R. (1991). The effect of soil water potential on seedling growth of some British plants. New Phytol. 118, 571-579. doi: 10.1111/j.1469-8137.1991.tb00998.x 
Forcella, F., Benech-Arnold, R. L., Sanchez, R., and Ghersa, C. M. (2000). Modeling seedling emergence. Field Crops Res. 67, 123-139. doi: 10.1016/S0378-4290(00)00088-5

Gallagher, R. S., and Cardina, J. (1998). Phytochrome-mediated Amaranthus germination effect of seed burial and germination temperature. Weed Sci. 46, 48-52. doi: 10.1017/S0043174500090159

Garcia-Huidobro, J., Monteith, J. L., and Squire, G. R. (1982). Time, temperature and germination of pearl millet (Pennisetum typhoides S. \& H.). I. constant temperature. J. Exp. Bot. 33, 288-296. doi: 10.1093/jxb/33.2.288

Gardarin, A., Guillemin, J-P., Munier-Jolain, N. M., and Colbach, N. (2010). Estimation of key parameters for weed population dynamics models: base temperature and base water potential for germination. Eur. J. Agron. 32, 162-168. doi: 10.1016/j.eja.2009.09.006

Ghersa, C. M., Benech-Arnold, R. L., and Martinez-Ghersa, M. A. (1992). The role of fluctuating temperatures in germination and establishment of Sorghum halepense (L.) Pers. Regulation of germination at increasing depths. Funct. Ecol. 6, 460-468. doi: 10.2307/2389284

Goudey, J. S., Saini, H. S., and Spencer, M. S. (1988). Role of nitrate in regulating germination of Sinapis arvensis L. (wild mustard). Plant Cell Environ. 11, 9-12. doi: 10.1111/j.1365-3040.1988.tb01770.x

Grime, J. P., Mason, G., Curtis, A. V., Rodman, J., and Band, S. R. (1981). A comparative study of germination characteristics in a local flora. J. Ecol. 69, 1017-1059. doi: 10.2307/2259651

Grundy, A. C., Phelps, K., Reader, R. J., and Burston, S. (2000). Modelling the germination of Stellaria media using the concept of hydrothermal time. New Phytol. 148, 433-444. doi: 10.1046/j.1469-8137.2000.00778.x

Gummerson, R. J. (1986). The effect of constant temperatures and osmotic potential on the germination of sugar beet. J. Exp. Bot. 37, 729-741. doi: $10.1093 / \mathrm{jxb} / 37.6 .729$

Gunsolus, J. L., and Buhler, D. D. (1999). "A risk management perspective on integrated weed management," in Expanding the Context of Weed Management, ed D. D Buhler (New York, NY: Haworth Press), 167-187. doi: 10.1300/J144v02n01_09

Hilhorst, H. W. M. (1990). Dose-response analysis of factors involved in germination and secondary dormancy of seeds of Sisymbrium officinale. II. nitrate. Plant Physiol. 94, 1096-1102. doi: 10.1104/pp.94.3.1096

Hilhorst, H. W. M., and Karssen, C. M. (1988). Dual effect of light on the gibberellin- and nitrate-stimulated seed germination of Sisymbrium officinale and Arabidopsis thaliana. Plant Physiol. 86, 591-597. doi: 10.1104/pp.86. 2.591

Hilton, J. R. (1982). An unusual effect of the far-red absorbing form of phytochrome: photoinhibition of seed germination in Bromus sterilis L. Planta 155, 524-528. doi: 10.1007/BF01607578

Hou, J. Q., and Simpson, G. M. (1993). Germination response to phytochrome depends on specific dormancy states in wild oat (A. fatua). Can. J. Bot. 71, 1528-1532. doi: 10.1139/b93-185

Jain, K. K., and Tiwari, J. P. (1995). Effects of herbicides and tillage operations on weeds, yield attributes and yield of soybean. Indian J. Weed Sci. 27, 32-35.

Johnson, W. C., and Mullinix, B. G. (1995). Weed management in peanut using stale seedbed technique. Weed Sci. 43, 293-297 doi: $10.1017 /$ S0043174500081200

Jones, R. E., and Medd, R. W. (2000). Economic thresholds and the case for longer term approaches to population management of weeds. Weed Technol. 14, 337-350. doi: 10.1614/0890-037X(2000)014[0337:ETATCF]2.0.CO;2

Karssen, C. M. (1980a). Patterns of change in dormancy during burial of seeds in soil. Israel J. Bot. 29, 65-73.

Karssen, C. M. (1980b). Environmental conditions and endogenous mechanisms involved in secondary dormancy of seeds. Israel J. Bot. 29, 45-64.

Karssen, C. M. (1982). "Seasonal patterns of dormancy in weed seeds," in The Physiology and Biochemistry of Seed Development, Dormancy and Germination, ed A. Khan (Amsterdam: Elsevier Biomedical Press), 243-270.

Karssen, C. M., and Hilhorst, H. W. M. (1992). "Effect of chemical environment on seed germination," in Seeds. The Ecology of Regeneration in Plant Communities. ed M. Fenner (Wallingford: CABI Publishing), 327-348.

Katoh, H., and Esashi, Y. (1975). Dormancy and impotency of cocklebur seeds I. $\mathrm{CO}_{2}, \mathrm{C}_{2} \mathrm{H}_{4}, \mathrm{O}_{2}$ and high temperature. Plant Cell Physiol. 16, 687-696.

Khan, A. A., and Karssen, C. M. (1980). Induction of secondary dormancy in Chenopodium bonus-henricus $L$. seeds by osmotic and high temperature treatments and its prevention by light and growth regulators. Plant Physiol. 66, 175-181. doi: 10.1104/pp.66.1.175

King, C. A., and Oliver, L. R. (1994). A model for predicting large crabgrass (Digitaria sanguinalis) emergence as influenced by temperature and water potential. Weed Sci. 42, 561-567. doi: 10.1017/S0043174500076955

Kruk, B. C., and Benech-Arnold, R. L. (1998). Functional and quantitative analysis of seed thermal responses in postrate knotweed (Polygonum aviculare) and common purslane (Portulaca oleracea). Weed Sci. 46, 83-90. doi: $10.1017 /$ S0043174500090214

Letchamo, W., and Gosselin, A. (1996). Light, temperature and duration of storage govern the germination and emergence of Taraxacum officinale seed. J. Hortic. Sci. 71, 373-377. doi: 10.1080/14620316.1996.11515416

Longchamps, L., Panneton, B., Simard, M. J., and Leroux, G. D. (2012). Could weed sensing in corn inter-rows result in efficient weed control? Weed Technol. 26, 649-656. doi: 10.1614/WT-D-12-00030.1

$\mathrm{Lu}, \mathrm{P}$., Sang, W., and Ma, K. (2006). Effects of environmental factors on germination and emergence of Crofton weed (Eupatorium adenophorum). Weed Sci. 54, 452-457. doi: 10.1614/WS-05-174R1.1

Malik, N., and Vanden Born, W. H. (1987). Germination response of Galium spurium $L$. to light. Weed Res. 27, 251-258. doi: 10.1111/j.1365-3180.1987.tb00761.x

Martinez-Ghersa, M. A., Satorre, E. H., and Ghersa, C. M. (1997). Effect of soil water content and temperature on dormancy breaking and germination of three weeds. Weed Sci. 45, 791-797. doi: 10.1017/S0043174500088986

Masin, R., Zuin, M. C., Archer, D. W., Forcella, F., and Zanin, G. (2005). WeedTurf: a predictive model to aid control of annual summer weeds in turf. Weed Sci. 53, 193-201. doi: 10.1614/WS-04-066R1

Merfield, C. N. (2013). False and Stale Seedbeds: The Most Effective Non-chemical Weed Management Tools for Cropping and Pasture Establishment. Lincoln: The BHU Future Farming Centre, 23.

Milberg, P., Andersson, L., and Thompson, K. (2000). Large-seeded spices are less dependent on light for germination than small-seeded ones. Seed Sci. Res. 10, 99-104. doi: 10.1017/S0960258500000118

Mohler, C. L. (1993). A model of the effects of tillage on emergence of weed seedlings. Ecol. Appl. 3, 53-73. doi: 10.2307/1941792

Mohler, C. L. (2001). "Weed life history: identifying vulnerabilities," in Ecological Management of Agricultural Weeds, eds M. Liebman, C. L. Mohler, and C. P. Staver (Cambridge: Cambridge University Press), 40-98. doi: $10.1017 /$ CBO9780511541810.003

Mulugeta, D., and Stoltenberg, D. E. (1997). Increased weed emergence and seed bank depletion by soil disturbance in a no-tillage system. Weed Sci. 45, 234-241. doi: $10.1017 /$ S0043174500092778

Murdoch, A. J., Roberts, E. H., and Goedert, C. O. (1989). A model for germination responses to alternating temperatures. Ann. Bot. 63, 97-111. doi: 10.1093/oxfordjournals.aob.a087733

Myers, M. W., Curran, W. S., Vangessel, M. J., Majek, B. A., Mortensen, D. A., Calvin, D. D., et al. (2005). Effect of soil disturbance on annual weed emergence in the northeastern United States. Weed Technol. 19, 274-282. doi: 10.1614/WT-03-242R1

Nandula, V. K., Eubank, T. W., Poston, D. H., Koger, C. H., and Reddy, K. N. (2006). Factors affecting germination of horseweed (Conyza canadensis). Weed Sci. 54, 898-902. doi: 10.1614/WS-06-006R2.1

Patil, B., Reddy, V. C., Ramachandra, P. T. V., Shankaralingappa, B. C., Devendra, R., and Kalyanamurthy, K. N. (2013). Weed management in irrigated organic finger millet. Indian J. Weed Sci. 45, 143-145. Available online at: http://www.indianjournals.com/ijor.aspx?target=ijor:ijws\&volume= 45\&issue $=2$ \&article $=017$

Peters, N. C. B. (1982). The dormancy of wild oat seed (Avena fatua L.) from plants grown under various temperature and soil moisture conditions. Weed Res. 22, 205-212. doi: 10.1111/j.1365-3180.1982.tb00165.x

Pierce, G. L., Warren, S. L., Mikkelsen, R. L., and Linker, H. M. (1999). Effects of soil calcium and $\mathrm{pH}$ on seed germination and subsequent growth of large crabgrass (Digitaria sanguinalis). Weed technol. 13, 421-424. doi: $10.1017 /$ S0890037X00041968

Riemens, M. M., Van Der Weide, R. Y., Bleeker, P. O., and Lotz, L. A. P. (2007). Effect of stale seedbed preparations and subsequent weed control in lettuce (cv. Iceboll) on weed densities. Weed Res. 47, 149-156. doi: $10.1111 / j .1365-3180.2007 .00554 . x$ 
Roberts, E. H. (1988). Temperature and seed germination. Soc. Exp. Biol. 42, 109-132.

Schönbeck, M. W., and Egley, G. H. (1981a). Phase-sequence of redroot pigweed seed germination responses to ethylene and other stimuli. Plant Physiol. 68, 175-179. doi: 10.1104/pp.68.1.175

Schönbeck, M. W., and Egley, G. H. (1981b). Changes in sensitivity of Amaranthus retroflexus L. seeds to ethylene during preincubation. I. constant temperatures. Plant Cell Environ. 4, 237-242. doi: 10.1111/1365-3040.ep116 11005

Schutte, B. J., Tomasek, B. J., Davis, A. S., Andersson, L., Benoit, D. L., Cirujeda, A., et al. (2013). An investigation to enhance understanding of the stimulation of weed seedling emergence by soil disturbance. Weed Res. 54, 1-12. doi: 10.1111/wre.12054

Shrestha, A., Roman, E. S., Thomas, A. G., and Swanton, C. J. (1999). Modeling germination and shoot-radicle elongation of Ambrosia artemisiffolia. Weed Sci. 47, 557-562. doi: 10.1017/S0043174500092262

Sindhu, P. V., Thomas, C. G., and Abraham, C. T. (2010). Seedbed manipulations for weed management in wet seeded rice. Indian J. Weed Sci. 42, 173-179. Available online at: http://www.indianjournals.com/ijor.aspx? target $=$ ijor $:$ ijws \&volume $=42$ \&issue $=3$ and 4 \&article $=008$

Singh, S., and Singh, M. (2009). Effect of temperature, light and $\mathrm{pH}$ on germination of twelve weed species. Indian J. Weed Sci. 41, 113-126. Available online at: http://www.indianjournals.com/ijor.aspx?target=ijor:ijws\&volume= 41\&issue $=3$ and $4 \&$ article $=001$

Smith, R. G. (2006). Timing of tillage is an important filter on the assembly of weed communities. Weed Sci. 54, 705-712. doi: 10.1614/WS-05177R1.1

Steinmann, H., and Klingebiel, L. (2004). Secondary dispersal, spatial dynamics and effects of herbicides on reproductive capacity of a recently introduced population of Bromus sterilis in an arable field. Weed Res. 44, 388-396. doi: 10.1111/j.1365-3180.2004.00413.x

Steinmaus, S. J., Prather, T. S., and Holt, J. S. (2000). Estimation of base temperatures for nine weed species. J. Exp. Bot. 51, 275-286. doi: 10.1093/jexbot/51.343.275

Stoller, E. W., and Wax, L. M. (1973). Periodicity of germination and emergence of some annual weeds. Weed Sci. 21, 574-580. doi: 10.1111/j.1365-3180.1973.tb01275.x

Swain, A. J., Hughes, Z. S., Cook, S. K., and Moss, S. R. (2006). Quantifying the dormancy of Alopecurus myosuroides seeds produced by plants exposed to different soil moisture and temperature regimes. Weed Res. 46, 470-479. doi: 10.1111/j.1365-3180.2006.00532.x

Symons, S. J., Naylor, J. M., Simpson, G. M., and Adkins, S. W. (1986). Secondary dormancy in Avena fatua: induction on characteristics in genetically pure dormant lines. Physiol. Plant. 68, 27-33. doi: 10.1111/j.1399-3054.1986.tb06591.x

Taylor, K. L., and Hartzler R, G. (2000). Effect of seed bank augmentation on herbicide efficacy. Weed Technol. 14, 261-267. doi: 10.1614/0890-037X(2000)014[0261:EOSBAO]2.0.CO;2

Taylorson, R. B. (1979). Response of weed seeds to ethylene and related hydrocarbons. Weed Sci. 27, 7-10. doi: 10.1017/S004317450004337X

Wright, K. J., Seavers, G. P., Peters, N. C. B., and Marshall, M. A. (1999). Influence of soil moisture on the competitive ability and seed dormancy of Sinapis arvensis in spring wheat. Weed Res. 39, 309-317. doi: 10.1046/j.1365-3180.1999.00147.x

Wyse, D. L. (1992). Future of weed science research. Weed Technol. 6, 162-165. doi: 10.1017/S0890037X00034497

Yoshioka, T., Satoh, S., and Yamasue, Y. (1998). Effect of increased concentration of soil $\mathrm{CO} 2$ on intermittent flushes of seed germination in Echinochloa crus-galli var. crus-galli. Plant Cell Environ. 21, 1301-1306. doi: 10.1046/j.1365-3040.1998.00347.x

Zhou, J., Deckard, E. L., and Ahrens, W. H. (2005). Factors affecting germination of hairy nightshade (Solanum sarrachoides) seeds. Weed Sci. 53, 41-45. doi: 10.1614/WS-04-100R1

Zimdahl, R. L. (1988). "The concept and application of the critical weed-free period," Pages in Weed Management in Agroecosystems: Ecological Approaches, eds M. A. Altieri and M. Liebman (Boca Raton, CRC Press), 145-155.

Conflict of Interest: The authors declare that the research was conducted in the absence of any commercial or financial relationships that could be construed as a potential conflict of interest.

Copyright (c) 2020 Travlos, Gazoulis, Kanatas, Tsekoura, Zannopoulos and Papastylianou. This is an open-access article distributed under the terms of the Creative Commons Attribution License (CC BY). The use, distribution or reproduction in other forums is permitted, provided the original author(s) and the copyright owner(s) are credited and that the original publication in this journal is cited, in accordance with accepted academic practice. No use, distribution or reproduction is permitted which does not comply with these terms. 